\title{
Meloxicam Administration in Dystocia Affected Bovines and its Impact on Release of Histamine
}

\author{
Umed Singh Mehra ${ }^{1 *}$, S.C. Arya ${ }^{2}$, Anupama Deora ${ }^{3}$, R.P. Diwakar ${ }^{4}$, \\ Pankaj Kumar ${ }^{5}$ and Rajendra Yadav ${ }^{6}$
}

\author{
${ }^{1}$ Department of Animal Husbandry and Dairying, Haryana, India \\ ${ }^{2}$ Department of Veterinary Gynaecology and Obstetrics, LUVAS, Hisar, \\ Haryana-125004, India \\ ${ }^{3}$ Deptartment of animal Biotechnology, LUVAS Hisar, India \\ ${ }^{4}$ Department of Veterinary Microbiology, C.V.Sc \& A.H., N.D.U.A\&T., \\ Kumarganj, Faizabad (U.P), India \\ ${ }^{5}$ Department of Veterinary Public Health and Epidemiology, LUVAS, Hisar, \\ Haryana-125004, India \\ ${ }^{6}$ Regional Referral Veterinary Diagnostic and Extension Centre (RVDEC), \\ Mahendergarh, India
}

\begin{tabular}{|c|c|}
\hline \multicolumn{2}{|r|}{ A B S T R A C T } \\
\hline & \multirow{5}{*}{$\begin{array}{l}\text { Dystocia is defined as delayed or difficult calving, sometimes requiring significant human } \\
\text { assistance. The levels of histamine in pregnancy were significantly different from those of } \\
\text { non-pregnant animals. Also the histamine levels in advanced pregnancy were significantly } \\
\text { lower than the animals with early or mid-pregnancy. So, the study was conducted to see } \\
\text { meloxicam administration in dystocia affected bovines and its impact on release of } \\
\text { histamine. Caesarean operated buffaloes which failed to survive following treatment had } \\
\text { significantly ( }<0.01 \text { ) higher histamine concentration in their blood before surgery which } \\
\text { further increased significantly by } 2 \text { hours post-surgery and remained significantly }(\mathrm{P}<0.05 \text { ) } \\
\text { higher than the survivors even up to } 24 \text { hours post treatment. Mean blood histamine levels } \\
\text { were found to be higher in buffaloes which died later on than those which survived } \\
\text { following treatment. Significantly ( } \mathrm{P}<0.05 \text { ) higher histamine concentration was observed } \\
\text { in buffaloes undergoing caesarean operation as compared to those treated by non-surgical } \\
\text { method. }\end{array}$} \\
\hline Keywords & \\
\hline $\begin{array}{l}\text { Meloxicam, } \\
\text { Histamine, } \\
\text { Caesarean }\end{array}$ & \\
\hline Article Info & \\
\hline $\begin{array}{l}\text { Accepted: } \\
\text { 22 April } 2018 \\
\text { Available Online: } \\
10 \text { May } 2018\end{array}$ & \\
\hline
\end{tabular}

\section{Introduction}

Amongst all domestic animals, cattle and buffalo are considered the species in which the incidence of dystocia appears to be highest. Although cattle and buffaloes appear to be similar in the parturition process but subtle differences are known to be existent in the anatomy and physiology of the birth canal between cows and buffaloes. Dystocia is one of the most important obstetrical conditions, and requires immediate attention by the veterinarians, for calving difficulty causes severe economic losses to the farmers. 
Bovines are the most commonly species affected with dystocia, which develops when the birth process is hindered by some physical obstacle or functional defect. Dystocia has been classified as maternal, fetal or placental in type (Sloss and Dufty, 1980). The levels of histamine in pregnancy were significantly different from those of non-pregnant animals. Also the histamine levels in advanced pregnancy were significantly lower than the animals with early or mid-pregnancy. Release of Histamine is associated with allergic reaction, as it causes both inflammatory response and contraction of smooth muscle tissue. Chemically, the histamine is 2-4imidazoly 1- ethylamine or $\square$-aminoethylimidazole. It is a polyamide formed by decarboxylation of precursor amino acid histidine, a reaction affected by the enzyme Lhistidine decarboxylase. Histamine is the principal cause of the acute-transient vascular phenomena that are responsible for producing the triple response reaction. Histamine is released by mast cells primarily when they degranulate due to IgE antibodies. Singh et al., (1974) determined biologically histamine content of 18 pregnant and non-pregnant buffaloes and found that the blood histamine increased significantly until 28th week of pregnancy after which it started decreasing. Keeping all these points in view the study was conducted to see meloxicam administration in dystocia affected bovines and its impact on release of histamine

\section{Materials and Methods}

The present investigation was carried out on 41 dystocia affected buffaloes brought to the teaching veterinary clinics, CCS HAU, Hisar for treatment. Before attempting to relieve the dystocia, a complete history of the case with regard to parity, stage of gestation, duration of problem and previous handling of the case by the field staff/laymen, was obtained from the owner.
The nature and cause of dystocia was determined on the basis of systemic examination and depending upon the cause of difficulty in birth and the duration and pervious handling of the case, obstetrical management was carried out.

All the animals received routine supportive therapy consisting of parentral antibiotics, dexamethasone, fluid therapy, hemostatic, uterine stimulants and intrauterine antiseptics post-delivery of the foetus.

\section{Grouping on the basis of obstetrical operation}

Group-I: comprised of 19 buffaloes in which foetus were removed by Caesarian section without administration of meloxicam prior to surgery.

Group II: was comprised of 22 caesarean operated buffaloes treated preemptively with meloxicam.

\section{Sub-grouping on the basis of obstetrical operation}

Group- $\mathrm{I}_{\mathrm{A}}$ consisted of 8 buffaloes in which dystocia were relieved by non-surgical techniques and without pre-emptive administration of meloxicam.

Group- $\mathrm{I}_{\mathrm{B}}$ comprised of 11 buffaloes in which foetus was removed by laparohysterotomy without administration of meloxicam prior to surgery.

Group $\mathrm{II}_{\mathrm{A}}$ included 8 meloxicam administered dystocia affected buffaloes treated nonsurgically.

Group $\mathrm{II}_{\mathrm{B}}$ was comprised of 14 caesarean operated buffaloes treated preemptively with meloxicam. 
Sub grouping on the basis of survival of dam following obstetrical management

Group S consisted of 24 buffaloes which survived following treatment.

Group D included 17 buffaloes which died during or after obstetrical operation.

Groups $S_{\text {I }}$ and $S_{\text {II }}$ consisted of 13 and 11 buffaloes respectively which survived without/with pre emptive administration of meloxicam.

Groups $D_{\text {I }}$ and $D_{\text {II }}$ were composed of six and 11 buffaloes respectively which died following obstetrical intervention without/with administration of meloxicam.

Groups $S_{B}$ and $D_{B}$ included 12 and 13 caesarean operated buffaloes respectively which survived or died following operation, Irrespective of treatment with Meloxicam.

\section{Sampling schedule}

Jugular blood samples were collected by standard venipuncture technique from all the cases before treatment (0hour) and then at 2 hours and 24 hours post-maneuovering.

Five $\mathrm{ml}$ of blood was kept in refrigerator for histamine assay. Blood histamine concentration was determined as per the procedure of KlimKina and Plitman (1989) as described by Gaudi (2004).

\section{Survivability/recovery of the animal}

The cases were followed and data was collected on recovery and survival of dam following treatment by interaction with the owner of the animal in order to correlate the observations on different parameters studied with survivability to arrive at possible prognostic indices.

\section{Statistical analysis}

The data was analyzed statistically using Duncan's Multiple Range test (Duncan 1955).

\section{Results and Discussion}

\section{Blood histamine}

Observation on blood histamine levels in different groups of dystocia affected buffaloes under present study have been presented in Table 1. Blood histamine concentration was significantly $(\mathrm{p}<0.05)$ increased at 2 hours following treatment of dystocia in all the groups.

The concentration declined significantly at 24 hours post-treatment in all the groups of treated animals when compared with the levels at 2 hours interval but were still significantly higher than the 0 hours levels.

However, there was no significant difference in histamine concentration between meloxicam administered and without meloxicam administration groups of buffaloes at any of the sampling interval.

Significantly $(\mathrm{P}<0.05)$ higher histamine concentration was observed in buffaloes undergoing caesarean operation as compared to those treated by non-surgical method (Table 2 ). The effect of surgery on blood histamine level was evident at both 2 and 24 hours post treatment whether the buffaloes were administered meloxicam or not.

Mean blood histamine levels were found to be higher in buffaloes which died later on than those which survived following treatment. Observation on histamine concentration in relation to survival of dystocia affected buffaloes has been presented in Table 3 . Caesarean operated buffaloes which failed to survive following treatment had significantly 
$(\mathrm{P}<0.01)$ higher histamine concentration in their blood before surgery which further increased significantly by 2 hours post-surgery and remained significantly $(\mathrm{P}<0.05)$ higher than the survivors even up to 24 hours post treatment.

Table.1 Effect of pre emptive administration of meloxicam on blood histamine concentration in dystocia affected buffaloes

\begin{tabular}{|c|c|c|c|}
\hline \multirow[t]{2}{*}{ Group } & \multicolumn{3}{|c|}{ Sampling interval Histamine ( $\mu$ Mol/L) } \\
\hline & 0 hour & 2 hours & 24 hours \\
\hline $\mathbf{I}(\mathbf{n}=19)$ & $576.484 \pm 12.105^{\mathrm{a}}$ & $968.565 \pm 37.915^{b}$ & $749.540 \pm 24.407^{c}$ \\
\hline $\mathrm{II}(\mathrm{n}=\mathbf{2 2})$ & $550.271 \pm 21.488^{a}$ & $932.420 \pm 44.152^{b}$ & $751.152 \pm 26.631^{\mathrm{c}}$ \\
\hline IA $(n=8)$ & $557.175 \pm 11.930^{\mathrm{a}}$ & $789.640 \pm 15.305^{b}$ & $648.940 \pm 20.017^{c}$ \\
\hline IIA $(\mathbf{n}=\mathbf{8})$ & $522.650 \pm 32.437^{\mathrm{a}}$ & $787.384 \pm 70.222^{b}$ & $\begin{array}{c}641.750 \\
\pm 19.745^{\mathrm{a}}\end{array}$ \\
\hline IB $(n=11)$ & $590.527 \pm 18.338^{\mathrm{a}}$ & $1092.056 \pm 26.860^{\mathrm{b}}$ & $822.725 \pm 19.422^{\mathrm{c}}$ \\
\hline $\begin{array}{c}\text { IIB } \\
(n=14)\end{array}$ & $\begin{array}{c}566.055 \\
\pm 28.208^{\mathrm{a}} \\
\end{array}$ & $\begin{array}{l}1017.520 \\
\pm 43.804^{b}\end{array}$ & $810.045 \pm 28.224^{c}$ \\
\hline
\end{tabular}

Means bearing different superscripts differ significantly $(\mathrm{P}<0.05)$ at different interval

Table.2 Effect of obstetrical operation on blood histamine concentration in dystocia affected buffaloes

\begin{tabular}{|c|c|c|c|}
\hline \multirow[t]{2}{*}{ Group } & \multicolumn{3}{|c|}{ Sampling interval Histamine ( $\mu \mathrm{mol} / \mathrm{L})$} \\
\hline & 0 hour & 2 hours & 24 hours \\
\hline I A (n=8) & $557.175 \pm 11.930 \mathrm{a}$ & $789.640 \pm 15.305 b$ & $648.940 \pm 20.017 c$ \\
\hline I B $(n=11)$ & $590.527 \pm 18.338 \mathrm{a}$ & $1092 . .056 \pm 26.860 b^{*}$ & $822.725 \pm 19.422 c^{*}$ \\
\hline II A $(n=8)$ & $522.650 \pm 32.437 \mathrm{a}$ & $787.384 \pm 70.222 b$ & $641.750 \pm 19.745 a$ \\
\hline II B $(n=14)$ & $566.055 \pm 28.208 a$ & $1017.520 \pm 43.804 b *$ & $810.045 \pm 28.224 c$ \\
\hline
\end{tabular}

Means bearing different superscripts differ significantly at different interval

* Significantly $(\mathrm{P}<0.05)$ different between groups at same interval

Table.3 Observation on blood histamine concentration and survivability in different groups of dystocia affected buffaloes

\begin{tabular}{|c|c|c|c|}
\hline \multirow[t]{2}{*}{ Group } & \multicolumn{3}{|c|}{ Sampling interval Histamine ( $\mu$ Mol/L) } \\
\hline & O hour & 2 hours & 24 hours \\
\hline$S(n=24)$ & $538.141 \pm 12.038$ & $901.676 \pm 25.043$ & $715.687 \pm 17.66$ \\
\hline D $(\mathbf{n}=17)$ & $596.69 \pm 23.97$ & $1021.458 \pm 59.141$ & $805.854 \pm 32.80$ \\
\hline S I (n=13) & $557.56 \pm 11.62$ & $919.99 \pm 38.11$ & $721.67 \pm 23.027$ \\
\hline D I $(n=6)$ & $617.47 \pm 21.81 *$ & $1073.80 \pm 74.80$ & $809.92 \pm 54.48$ \\
\hline S II (n=11) & $515.18 \pm 20.93$ & $880.030 \pm 31.63$ & $708.61 \pm 28.36$ \\
\hline D II (n=11) & $585.35 \pm 35.42$ & $990.049 \pm 84.67$ & $803.14 \pm 43.58$ \\
\hline S B $(n=12)$ & $527.337 \pm 16.389$ & $989.876 \pm 31.737$ & $776.00 \pm 20.57$ \\
\hline D B $(n=13)$ & $622.501 \pm 24.485^{* * *}$ & $1113.571 \pm 37.665 *$ & $855.694 \pm 23.46 *$ \\
\hline
\end{tabular}


A significant rise in blood histamine concentration was recorded within 2 hours of handling of dystocia in all the groups which was followed by a significant decline by 24 hours post treatment when compared with the level at 2 hours interval though the levels were still significantly $(\mathrm{P}<0.01)$ higher than the pre-treatment levels. This increase in blood histamine concentration following treatments of dystocia is in agreement with the observation of Gagan Gaudi (2004) in dystocia affected buffaloes. However, in his study the levels at 24 hours post treatment were found to be almost identical with the pre-treatment levels. Matharu and Prabhakar (1999) reported that the initial blood histamine levels which were significantly higher in torsion affected buffaloes than the normal calving, ones, almost doubled following detorsion of uterus and/or caesarean section. Singh (2002) and Gaudi (2004) maintained that the blood histamine concentration in dystocia cases remained significantly higher than the corresponding control even upto 48 hours post treatment despite the fact that the levels registered a non-significant decline at this interval.

The damage to uterine endometrium and musculature caused by dystocia might result in abnormal synthesis and release of histamine or histamine like substances (Guyton, 1995). The fall in blood histamine levels at 24 hours post treatment could be as a consequence of reduction of stress as well as lowering of circulating oestogen concentration by this time (Vasishta, 1983 and Matharu, 1997).

Preemptive administration of meloxicam in dystocia affected buffaloes had no influence on blood histamine concentration. There is no parallel report in the available literature to confirm or repute our findings. The blood histamine concentration were found to be significantly $(\mathrm{P}<0.05)$ higher in caesarean operated buffaloes than the buffaloes handled non surgically. This indicates greater tissue damage and higher degree of stress after caesarean operation in such cases as compared to the animals in which dystocia is relieved by non-surgical means. This is well supported by our observations on plasma cortisol levels following caesarean section.

Blood histamine concentration were recorded to be higher in those buffaloes which died subsequently despite treatment as compared to those which survived, the difference being highly significant in caesarean operated buffaloes. This confirms the earlier report by Gaudi (2004) in this regard. Administration of antihistaminics has been reported to improve the survival rate in dystocia affected buffaloes (Gaudi et al., 2006).

Blood histamine levels increased significantly following treatment of dystocia and registered significant decline at 24 hours post treatment in comparison to the concentration at 2 hours post treatment. The levels were much higher in surgically treated buffaloes than the nonsurgically handled cases and in buffaloes which died subsequently. Administration of meloxicam had no effect on blood histamine concentration.

\section{References}

Duncan, D.B. (1955). Multiple range and multiple F tests. Biom. 11: 1-42 (Cited by Snedecor and Cochran, 1967).

Gaudi, G. (2004). Studies on pathophysiology of Bovine Dystocia with special reference to Energy metabolism. M.V.Sc. Thesis. Haryana Agric. Univ., Hisar, India.

Gaudi, G., Chander, S., Luthra, R.A. and Nanda, T. (2006). Blood histamine profile and survivability following antihistaminic therapy in dystocia affected buffaloes. Proceedings of $6^{\text {th }}$ 
Indian Veterinary Congress at Orissa University of Agriculture and Technology. Bhubaneshwar, April. 2006.

Guyton, A.C. (1995). Textbook of medical physiology. $7^{\text {th }}$ ed. W.B. Saunders Company, Philadelphia.

Klimkina, N.V. and Plitman, S.I. (1989). Laboratory manual in Biochemistry. Storey EA and Makarova VG (Eds.). $2^{\text {nd }}$ edn. Min. Publishers, Moscow, 20709.

Matharu, S.S. (1997). Endocrinlogical and histopathological investigation on corpus luteum and uterus of Buffaloes effected with uterine torsion. M.V.Sc. Thesis. Punjab Agric. Univ., Ludhiana, India.

Matharu, S.S. and Prabhakar, S. (1999). Clinical observation and success of treatment of uterine torsion in
Buffaloes. Indian J. Anim. Repord.22: 45-48.

Singh, S. (2002). Studies on toxemic status in dystocia affected buffaloes. M.V.Sc. Thesis Punjab Agric. Univ., Ludhiana, India.

Singh, T.J., Misra, S.N., Paul, B.S. and Takkar, O.P. (1974). Blood concentration of histamine and 5hydroxytryptamine and histaminase in pre-parturient buffaloes. Indian J. Anim. Sci. 44(2): 99-100.

Sloss, V. and J. H. Dufty. (1980). Handbook of Bovine Obstetrics. Williams and Wilkins, Baltimore, USA. 208p.

Vasishta, N.K. (1983). Torsion of uterus in Buffaloes in relation to Incidence, etiology and treatment M.V.Sc. Thesis submitted to Punjab Agricultural University, Ludhiana, India.

\section{How to cite this article:}

Umed Singh Mehra, S.C. Arya, Anupama Deora, R.P. Diwakar, Pankaj Kumar and Rajendra Yadav. 2018. Meloxicam Administration in Dystocia Affected Bovines and Its Impact on Release of Histamine. Int.J.Curr.Microbiol.App.Sci. 7(05): 3341-3346.

doi: https://doi.org/10.20546/ijcmas.2018.705.390 